\title{
lon-Exchange-Induced Selective Etching for the Synthesis of Amino-Functionalized Hollow Mesoporous Silica for Elevated-High-Temperature Fuel Cells
}

Zhang, Jin ; Liu, Jian ; Lu, Shanfu ; Zhu, Haijin; Aili, David; Marco, Roland De ; Xiang, Yan ; Forsyth, Maria; Li, Qingfeng; Jiang, San Ping

Published in:

A C S Applied Materials and Interfaces

Link to article, DOI:

10.1021/acsami.7b09591

Publication date:

2017

Document Version

Peer reviewed version

Link back to DTU Orbit

Citation (APA):

Zhang, J., Liu, J., Lu, S., Zhu, H., Aili, D., Marco, R. D., Xiang, Y., Forsyth, M., Li, Q., \& Jiang, S. P. (2017). IonExchange-Induced Selective Etching for the Synthesis of Amino-Functionalized Hollow Mesoporous Silica for Elevated-High-Temperature Fuel Cells. A C S Applied Materials and Interfaces, 9(37), 31922-31930.

https://doi.org/10.1021/acsami.7b09591

\section{General rights}

Copyright and moral rights for the publications made accessible in the public portal are retained by the authors and/or other copyright owners and it is a condition of accessing publications that users recognise and abide by the legal requirements associated with these rights.

- Users may download and print one copy of any publication from the public portal for the purpose of private study or research.

- You may not further distribute the material or use it for any profit-making activity or commercial gain

- You may freely distribute the URL identifying the publication in the public portal 


\title{
Ion Exchange Induced Selective Etching for the Synthesis of Amino- Functionalized Hollow Mesoporous Silica for Elevated High Temperature Fuel Cells
}

Jin Zhang, ${ }^{\text {a,b }}$ Jian Liu, ${ }^{\mathrm{b}}$ Shanfu Lu, ${ }^{\mathrm{a}}$ Haijin Zhu, ${ }^{\mathrm{c}}$ David Aili, ${ }^{\mathrm{d}}$ Roland De Marco, ${ }^{\mathrm{b}, \mathrm{e}}$ Yan Xiang, ${ }^{\mathrm{a}}$ Maria Forsyth, ${ }^{\mathrm{c}}$ Qingfeng Li, ${ }^{\mathrm{d}}$ and San Ping Jiang*,b,e

${ }^{a}$ Beijing Key Laboratory for Bio-inspired Energy Materials and Devices, School of Space and Environment, Beihang University, Beijing, 100191, China.

${ }^{b}$ Fuels and Energy Technology Institute \& Department of Chemical Engineering, Curtin University, Perth, WA6102, Australia.

${ }^{c}$ Institute for Frontier Materials, Deakin University, Geelong, VIC 3220, Australia.

${ }^{d}$ Department of Energy Conversion and Storage, Technical University of Denmark, Kemitorvet 207, DK-2800, Lyngby, Denmark.

e Faculty of Science, Health, Education and Engineering, University of Sunshine Coast, Maroochydore DC, QLD 4558, Australia.

*Corresponding author. E-mail address: s.jiang@curtin.edu.au (SP Jiang)

Keywords: Proton exchange membrane fuel cells (PEMFCs); High temperature proton exchange membranes (HT-PEMs); PES-PVP composite polymer; Amino-functionalized hollow mesoporous silica ( $\mathrm{NH}_{2}$-HMS); Phosphotungstic acid (PWA); Ion exchange induced selective etching.

\begin{abstract}
:
As differentiated from conventional synthetic processes, amino-functionalized hollow mesoporous silica $\left(\mathrm{NH}_{2}\right.$-HMS) has been synthesized using a new and facile strategy of ionexchange induced selective etching of amino-functionalized mesoporous silica $\left(\mathrm{NH}_{2}-\right.$ meso-
\end{abstract}


silica) by an alkaline solution. Nuclear magnetic resonance (NMR) spectroscopy and in situ time resolved small angle X-ray scattering (SAXS) reveal that ion-exchange induced selective etching arises from the gradient distribution of $\mathrm{OH}^{-}$in the $\mathrm{NH}_{2}$-meso-silica nanospheres. Moreover, the ion-exchange induced selective etching mechanism is verified through a successful synthesis of hollow mesoporous silica. After infiltration with phosphotungstic acid (PWA), PWA-NH2-HMS nanoparticles are dispersed in the polyethersulfonepolyvinylpyrrolidone (PES-PVP) matrix, forming a hybrid PWA-NH 2 -HMS/PES-PVP nanocomposite membrane. The resultant nanocomposite membrane with an optimum loading of $10 \mathrm{wt} \%$ of PWA-NH$-\mathrm{NMS}$ showed an enhanced proton conductivity of $0.175 \mathrm{~S} \mathrm{~cm}^{-1}$ and peak power density of $420 \mathrm{~mW} \mathrm{~cm}^{-2}$ at $180{ }^{\circ} \mathrm{C}$ under anhydrous conditions. Excellent durability of the hybrid composite membrane fuel cell has been demonstrated at $200{ }^{\circ} \mathrm{C}$. The results of this study demonstrated the potential of the facile synthetic strategy in the fabrication of $\mathrm{NH}_{2}-$ HMS with controlled mesoporous structure for application in nanocomposite membranes as a technology platform for elevated temperature proton exchange membrane fuel cells.

\section{Introduction}

Hollow mesoporous silica (HMS) has attracted increasing attention due to its unique structure with mesoporous channels for accelerated mass transport and void space for mass storage and catalysis. ${ }^{1-3}$ In recent years, there has been much effort devoted to the functionalization of HMS by organic groups because of their superior biocompatibility, high adsorption capability and enhanced proton conductivity. ${ }^{4-5}$ Amino-functionalized hollow mesoporous silica $\left(\mathrm{NH}_{2}-\mathrm{HMS}\right)$ is a promising material in applications for drug release, removal of heavy metal ions and fuel cells. ${ }^{6-10}$ Yin et al. showed that by adding small amounts of $\mathrm{NH}_{2}-\mathrm{HMS}$, the proton conductivity of Nafion membrane increased by over 11 times at $80{ }^{\circ} \mathrm{C}$ and low relative humidity. ${ }^{8}$ In our previous work, the addition of $\mathrm{NH}_{2}$-HMS successfully improved the proton conductivity of an 
acid-base composite membrane by forming a hydrogen-bonding network between $-\mathrm{NH}_{2}$ and phosphoric acid. ${ }^{11}$ However, fabrication of $\mathrm{NH}_{2}-\mathrm{HMS}$ is generally based on a post aminofunctionalization strategy. In this case, $\mathrm{NH}_{2}$ - $\mathrm{HMS}$ is formed by sequential steps including the formation of hard or soft templates, coverage of mesoporous silica layer on templates, removal of templates and amino-functionalization. This strategy not only gives rise to complicated synthetic procedures, but also results in the non-uniform distribution of $-\mathrm{NH}_{2}$ groups. ${ }^{12}$

In this regard, several new strategies have been developed to fabricate $\mathrm{NH}_{2}-\mathrm{HMS}$ nanoparticles. ${ }^{13-14}$ For example, $\mathrm{NH}_{2}$-HMS was synthesized by a sequential procedure involving a step-by-step post-grafting and spontaneous phase transformation. ${ }^{15} \mathrm{Yu}$ and coworkers employed an oil phase as a soft template to form the void and used a co-condensation protocol to form the amino-functionalized mesoporous silica. ${ }^{16}$ Similarly, Yin et al. used the oil phase of amine silane as a soft template to form the $\mathrm{NH}_{2}$-HMS via a co-condensation process in solution in a single step. ${ }^{17}$ However, those approaches either lead to disordered mesoporous channels in the shell, or require further surface modification to introduce reactive functional groups to the materials. ${ }^{18}$ Moreover, the formation mechanism of $\mathrm{NH}_{2}-\mathrm{HMS}$ is seldom investigated and verified by in situ characterization techniques, although several theories have been introduced including surface protected etching, Ostwald ripening and cationic surfactant assisted selective etching. ${ }^{18-19}$ This is mostly due to the harsh synthetic conditions of hydrothermal treatments. ${ }^{20}$ To date, it is still a challenge to develop a facile approach to fabricate $\mathrm{NH}_{2}-\mathrm{HMS}$ with controlled mesoporous structure.

Besides the complexity of synthetic methods, there are two major factors that hinder the application of $\mathrm{NH}_{2}-\mathrm{HMS}$ in fuel cells including its intrinsic non-conductivity characteristics and the poor durability of proton exchange membranes (PEMs) operated at elevated temperatures in fuel cell. ${ }^{11}$ However, impregnation of phosphotungstic acid (PWA) in mesoporous silica has been proven to be an effective approach to increase the proton 
conductivity of the pure inorganic material. ${ }^{21-23}$ Moreover, we have recently discovered that the addition of PWA impregnated mesoporous silica composite significantly increased the durability of polybenzimidazole membrane at $200{ }^{\circ} \mathrm{C} .{ }^{24}$ Accordingly, a combination of PWA and $\mathrm{NH}_{2}$-HMS in PEMs is an efficacious way to increase the proton conductivity and durability of composite membranes in fuel cells operated at high temperatures.

Herein, we report on a novel and facile strategy to fabricate $\mathrm{NH}_{2}-\mathrm{HMS}$ via an ion exchange induced selective method that forms controlled hollow cores with highly ordered mesoporous shells. The mechanism of formation of $\mathrm{NH}_{2}-\mathrm{HMS}$ was investigated by nuclear magnetic resonance (NMR) and in situ time-resolved synchrotron small angle X-ray scattering (SAXS). PWA was impregnated in the mesopores of the $\mathrm{NH}_{2}-\mathrm{HMS}$ nanoparticles (i.e., $\mathrm{PWA}^{-\mathrm{NH}_{2}-}$ HMS). When the as-synthesized PWA-NH $2-H M S$ was incorporated into a PES-PVP polymer matrix, this novel hybrid PEM showed significantly enhanced proton conductivity and durability at $200{ }^{\circ} \mathrm{C}$, demonstrating the potential for applications in fuel cells operating at elevated temperatures.

\section{Experimental}

\subsection{Materials}

Phosphotungstic acid $\left(\mathrm{H}_{3} \mathrm{PW}_{13} \mathrm{O}_{40} \cdot n \mathrm{H}_{2} \mathrm{O}\right.$, PWA), tetroethyl orthosilicate (TEOS), (3aminopropyl)triethoxysilane (APTES), cetyltrimethylammonium bromide (CTAB), N-methyl2-pyrrolidone (NMP) and sodium carbonate were purchased from Sigma-Aldrich and used without purification. Anhydrous ethanol (EtOH), aqueous $\mathrm{HCl}(32 \mathrm{wt} \%)$, phosphoric acid (85 wt $\left.\% \mathrm{H}_{3} \mathrm{PO}_{4}\right)$ and ammonia $\left(28 \mathrm{wt} \%, \mathrm{NH}_{3} \cdot \mathrm{H}_{2} \mathrm{O}\right)$ were obtained from Rowe Scientific, Australia. The PVP360 $\left(\mathrm{M}_{\mathrm{w}}=360000 \mathrm{~g} \mathrm{~mol}^{-1}\right)$ and PVP40 $\left(\mathrm{PVP} 40, \mathrm{M}_{\mathrm{w}}=40000 \mathrm{~g} \mathrm{~mol}^{-1}\right)$ materials were obtained from Sigma-Aldrich, while PES (Veradel ${ }^{\circledR}$ A301) was obtained from Solvay, Belgium. The Pt/C catalyst (50 wt\%) was purchased from Alfa Aesar, USA. 


\subsection{Formation of $\mathrm{NH}_{2}-\mathrm{HMS}$}

As a typical recipe for the synthesis of $\mathrm{NH}_{2}$-meso-silica, a mixture of $\mathrm{H}_{2} \mathrm{O}$ : EtOH: $\mathrm{NH}_{3} \cdot \mathrm{H}_{2} \mathrm{O}$ : CTAB: APTES: TEOS with a molar ratio of 2756: 518: 3.9: 0.40: 0.11: 1.0 was prepared. CTAB was dissolved in a mixed solution of $250 \mathrm{~mL}$ Milli-Q water and $150 \mathrm{~mL}$ EtOH. Subsequently, $\mathrm{NH}_{3} \cdot \mathrm{H}_{2} \mathrm{O}(28 \mathrm{wt} \%)$ was added to the solution, followed by the addition of TEOS and APTES. The mixed solution was stirred at room temperature for $6 \mathrm{~h}$ with the initially transparent solution turning into an opaque suspension. The white solid was collected from the suspension by centrifugation at $10000 \mathrm{rpm}$ for $10 \mathrm{~min}$, hereafter named as $\mathrm{NH}_{2}$-mesosilica/CTAB. After that, the white solid was dispersed into $50 \mathrm{~mL}$ of water after being washed twice with water and EtOH. Subsequently, the suspension was treated in a $\mathrm{Na}_{2} \mathrm{CO}_{3}$ solution at $60{ }^{\circ} \mathrm{C}$ under stirring for $2 \mathrm{~h}$, followed by filtration. This process also selectively etched the meso-silica, forming hollow meso-silica (HMS). The collected solid, hereafter named as $\mathrm{NH}_{2}$ $\mathrm{HMS} / \mathrm{CTAB}$, was washed with water and $\mathrm{EtOH}$ and dried for $8 \mathrm{~h}$ at $50{ }^{\circ} \mathrm{C}$. The CTAB surfactant was extracted by a solution with $100 \mathrm{~mL}$ of EtOH and $3.0 \mathrm{~mL}$ of $\mathrm{HCl}(32 \mathrm{wt} \%)$ at $80{ }^{\circ} \mathrm{C}$ for $3 \mathrm{~h}$. After the CTAB extraction, $\mathrm{NH}_{2}$-meso-silica/CTAB and $\mathrm{NH}_{2}-\mathrm{HMS} / \mathrm{CTAB}$ were marked as $\mathrm{NH}_{2}$-meso-silica and $\mathrm{NH}_{2}-\mathrm{HMS}$, respectively.

\subsection{Fabrication of $P W A-N_{2}-H M S / P E S-P V P$ membranes}

PWA- $\mathrm{NH}_{2}-\mathrm{HMS}$ was fabricated by impregnating PWA into the mesopores of the $\mathrm{NH}_{2}$ HMS spheres via a vacuum impregnation method. ${ }^{25}$ The loading of PWA in $\mathrm{NH}_{2}$-HMS was $40.0 \mathrm{wt} \%$. Certain amounts of inorganic fillers were mixed into a PES-PVP solution in NMP. The dispersion was poured to a petri dish at room temperature, followed by treatment at 100 ${ }^{\circ} \mathrm{C}$ for $24 \mathrm{~h}$ and then at $120{ }^{\circ} \mathrm{C}$ for another $24 \mathrm{~h}$. Subsequently, the membranes were detached

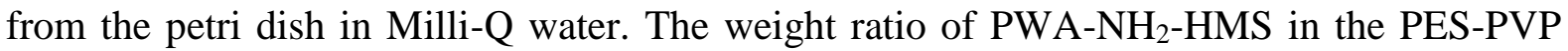
membranes were 5.0, 10.0 and $15.0 \mathrm{wt} \%$. A membrane with $10 \mathrm{wt} \% \mathrm{NH}_{2}-\mathrm{HMS}$ without infiltration of PWA was prepared for comparison. The thickness of the dry composite 
membranes was in the range of $50-80 \mu \mathrm{m}$. Finally, the membranes were imbibed with phosphoric acid in $85 \mathrm{wt} \% \mathrm{H}_{3} \mathrm{PO}_{4}$ at room temperature for one week.

\subsection{Characterization}

Microstructural and elemental distribution characteristics of the inorganic powders were examined by a high-angle annular dark field (HAADF) scanning transmission electron microscopy (STEM) using FEI Titan G2 STEM at an acceleration voltage of $200 \mathrm{kV}$. All nuclear magnetic resonance spectra were measured at Bruker Avance III $200 \mathrm{MHz}$ widebore NMR spectrometer equipped with a 4 mm MAS probe. ${ }^{13} \mathrm{C}$ CP-MAS NMR spectra were recorded at $10 \mathrm{kHz}$ mas with a recycling delay of $2 \mathrm{~s}$. Quantitative ${ }^{29} \mathrm{Si}$ MAS NMR spectra were measured using single pulse excitation sequence, with a small flip angle of $5^{\circ}$ and a recycling delay of $40 \mathrm{~s}$, under $10 \mathrm{kHz}$ MAS, and 4096 scans were accumulated in order to achieve a sufficient signal-to-noise ratio. Nitrogen adsorption isotherms, Brunauer-EmmettTeller (BET) specific surface areas and the porosity of the samples were measured at $-196{ }^{\circ} \mathrm{C}$ using a Micromeritics ASAP 2020 gas adsorption instrument. Before the adsorption measurements, the membranes were cut into small pieces and degassed at $100{ }^{\circ} \mathrm{C}$ for $9 \mathrm{~h}$. With the in situ time-resolved SAXS characterization, liquids were pumped into a capillary in the beamline via a syringe pump, and the temperatures of liquids were precisely controlled using a water bath. For the SAXS analysis of solid powders, they were attached to the surface of a flat plate sample holder with holes. The beam energy was $12 \mathrm{KeV}$, and the camera length was $500 \mathrm{~mm}$ with $q$ range from 0.022 to $1.151 \AA^{-1}$. Scanning electron microscopy (SEM, Zeiss Neon $40 \mathrm{EsB}$ ) with an accelerating voltage of $5 \mathrm{kV}$ was employed to study the cross-sectional morphology of the composite membranes. Stress-strain curves were recorded using a Testometric Micro 350 under ambient conditions and a crosshead speed of $10.00 \mathrm{~mm} \mathrm{~min}^{-1}$. The specimens were die-cut to a dog-bone shape with a gauge length and width of 28 and 2 $\mathrm{mm}$, respectively. 
A Pt/C electrode was used in both the anode and cathode. Two Pt/C catalyst electrodes based on Toray ${ }^{\circledR}$ TGP-H-060 carbon paper were hot pressed with a PES-PVP composite membrane at $180{ }^{\circ} \mathrm{C}$ and $10 \mathrm{MPa}$ for $1 \mathrm{~min}$ to form a membrane-electrode-assembly (MEA). The loading of Pt and PVP ionomer (PVP40) in both anode and cathode was 0.26 and $0.13 \mathrm{mg}$ $\mathrm{cm}^{-2}$, respectively. Subsequently, the MEA was mounted in a single-cell hardware (active area $4.0 \mathrm{~cm}^{-2}$ ) for the cell performance measurement using a Greenlight G20 fuel cell test station with a flow rate of 50 and $100 \mathrm{~mL} \mathrm{~min}^{-1}$ with dry $\mathrm{H}_{2}$ and $\mathrm{O}_{2}$, respectively. The in situ proton conductivity of PES-PVP composite membranes was measured under an anhydrous condition with an Ivium potentiostat using electrochemical impedance spectroscopy at frequencies ranging from $1 \mathrm{MHz}$ to $10 \mathrm{~Hz}$ with an amplitude voltage of $10 \mathrm{mV}$ in the temperature range of 120 to $180^{\circ} \mathrm{C}$. The performance of cells with different PES-PPV composite membrane with different loadings of PWA-NH $2-H M S$ as well as pristine PES-PVP membrane was measured at $180{ }^{\circ} \mathrm{C}$, and the stability of cells with different PES-PVP composite membranes was evaluated at $200{ }^{\circ} \mathrm{C}$ under a current density of $200 \mathrm{~mA} \mathrm{~cm}{ }^{-2}$. The reason for testing the cell stability at $200^{\circ} \mathrm{C}$ is to accelerate the degradation process of PA doped PES-PVP composite based membrane cells.

\section{Results and discussion}

\subsection{Synthesis of $\mathrm{NH}_{2}-\mathrm{HMS}$}

Figure 1A presents a TEM image of $\mathrm{NH}_{2}$-meso-silica with a solid core. These particles were formed using a ratio of $10 \mathrm{~mol} \%$ APTES to TEOS, while the concentration of CTAB was $8 \mathrm{mmol} \mathrm{L}{ }^{-1}$. After etching in an aqueous $\mathrm{Na}_{2} \mathrm{CO}_{3}$ solution $\left(0.3 \mathrm{~mol} \mathrm{~L}^{-1}\right)$ for $2 \mathrm{~h}$, the interior of $\mathrm{NH}_{2}$-meso-silica particles were removed, while the mesoporous shells were left intact (see Figs. $1 \mathrm{~B}$ and $\mathrm{C})$. Lattice fringes were observed as parallel lines running across the surfaces of the walls and ordered mesoporous channels as observed at the edge of the spheres (see Fig. 1D). 
Moreover, the white dots in the FFT image of the inset of Figure 1D further demonstrate the orderly nature of the mesopores. A solid-state ${ }^{13} \mathrm{C}$ CP-MAS NMR spectrum (see Fig. 2A) confirms the presence of carbon atom, while the ${ }^{29} \mathrm{Si}$ MAS NMR spectrum (see Fig. 2B) revealed chemical shifts at $66,93,100$ and $110 \mathrm{ppm}$ corresponding to functionalized silicate species, viz., $\mathrm{Q}_{2}\left[(\mathrm{SiO})_{2} \mathrm{Si}(\mathrm{OEt})_{2}\right], \mathrm{Q}_{3}\left[(\mathrm{SiO})_{3} \mathrm{SiOEt}\right]$ and $\mathrm{Q}_{4}\left[(\mathrm{SiO})_{4} \mathrm{Si}\right]$, respectively. ${ }^{26} \mathrm{These}$ results suggest that there has been condensation of APTES into the hybrid particles. It should be noted that the $\mathrm{NH}_{2}$-meso-silica particles were also obtained with a ratio of $20 \mathrm{~mol} \%$ APTES to TEOS, while the mesoporous structures of these particles deteriorated after the etching treatment. Moreover, neither $\mathrm{NH}_{2}$-meso-silica nor $\mathrm{NH}_{2}$-HMS was obtained with $30 \mathrm{~mol} \%$ APTES. These results demonstrate that the use of excess organosilane molecules disrupts the packing of surfactants, and consequently, induces an alteration in the geometry of surfactant micelles that affects the assembly between the silica and micelle complexes. ${ }^{13,27}$ Consequently, the APTES content was fixed at $10 \mathrm{~mol} \%$ in all subsequent preparations.

\subsection{Ion exchange induced selective etching by $\mathrm{Na}_{2} \mathrm{CO}_{3}$}

The concentration of etchant, $\mathrm{Na}_{2} \mathrm{CO}_{3}$, was found to significantly influence the formation of $\mathrm{NH}_{2}-\mathrm{HMS}$ particles. After etching in $0.1 \mathrm{~mol} \mathrm{~L}^{-1}$ aqueous solution of $\mathrm{Na}_{2} \mathrm{CO}_{3}$, the centre of the $\mathrm{NH}_{2}$-meso-silica/CTAB spheres collapsed into silica colloids, while the outer portions of the spheres remained intact (see Fig. 3A). At higher concentrations of the $\mathrm{Na}_{2} \mathrm{CO}_{3}$ etchant, the hollow mesoporous structure became more regular and clearly distinguishable (see Fig. 3B, C). However, with a further increase in $\mathrm{Na}_{2} \mathrm{CO}_{3}$ concentration to $0.4 \mathrm{~mol} \mathrm{~L}^{-1}$, the mesoporous shell started to break into silica fragments (see Fig. 3D). According to Figure 3E, quantitative ${ }^{29} \mathrm{Si}$ MAS NMR analysis of the pristine $\mathrm{NH}_{2}$-meso-silica material showed that $14.1 \%$ of the silicon atoms in the mesoporous hybrid spheres were at T sites, and $85.9 \%$ of the silicon atoms were at Q sites (see Fig. 3F), which is consistent with the material composition calculated using the molar ratios of the APTES and TEOS precursors. After the etching treatment, the amount of 
silicon atoms in the $\mathrm{NH}_{2}-\mathrm{HMS}$ decreased with an increase of the concentration of the etchant. After etching in $0.4 \mathrm{~mol} \mathrm{~L}^{-1} \mathrm{Na}_{2} \mathrm{CO}_{3}$ at $60{ }^{\circ} \mathrm{C}$ for $2 \mathrm{~h}$, only $4.5 \%$ of the silicon atoms remained at $\mathrm{T}$ sites. Moreover, the indicative factor representing the degree of condensation of silicate, $\mathrm{Q}_{4} /\left(\mathrm{Q}_{3}+\mathrm{Q}_{2}\right){ }^{28}$ decreased when switching from solution containing 0 to $0.3 \mathrm{~mol} \mathrm{~L}^{-1} \mathrm{Na}_{2} \mathrm{CO}_{3}$ (see Table S1), demonstrating that dissolution of silicates at high degrees of silica condensation from high concentrations of etchant. In other words, not only the soft interior but also the hard outer portions of the spheres are dissolved by the etchant.

To investigate the formation process of $\mathrm{NH}_{2}-\mathrm{HMS}$ particles, an in situ time-resolved synchrotron SAXS study was undertaken to monitor the transformation of $\mathrm{NH}_{2}$-mesosilica/CTAB to $\mathrm{NH}_{2}-\mathrm{HMS} / \mathrm{CTAB}$, with the results presented in Figure 4. A unique peak centered at $q=0.145 \AA^{-1}$ (Fig. 4A), corresponding to the (100) plane of the $\mathrm{NH}_{2}-$ mesosilica/CTAB particles, remained essentially constant during the etching treatment (see Fig. 4B) while the particles were treated at a low concentration of $\mathrm{Na}_{2} \mathrm{CO}_{3}$ solution (viz., $0.1 \mathrm{~mol} \mathrm{~L}^{-1}$ ). Moreover, the average particle size of the $\mathrm{NH}_{2}$-meso-silica/CTAB particles was identical to the pristine particles prior to the etching treatment (see Fig. 4C). The results indicate that the mesoporous structure and the morphology of the particles are preserved throughout the etching process. However, the peak intensity of the (100) plane showed a V-shaped curve on extended etching, reaching a minimum after $20 \mathrm{~min}$ (see Fig. 4B) that is consistent with a loose structure in the interior portion of the $\mathrm{NH}_{2}-m e s o$-silica/CTAB particles (see Fig. 3A). The partial silicate dissolution decreases the distortion of the mesoporous channels, resulting in a decrease in the intensity of this peak. When the $\mathrm{NH}_{2}$-meso-silica/CTAB particles were etched in $\mathrm{Na}_{2} \mathrm{CO}_{3}$ at a high concentration of $0.3 \mathrm{~mol} \mathrm{~L}^{-1}$, the peak intensity of the (100) plane decreased to a minimum after 15 min (see Fig. 4E), faster than the rate observed for treated particles at a low concentration of $\mathrm{Na}_{2} \mathrm{CO}_{3}$. This indicates that a steeply facilitated solid-to-hollow transformation process occurs as a function of the concentration of the etching agent. Moreover, 
the $q$ range for the (100) plane shifted from $0.142 \AA^{-1}(\mathrm{t}=1 \mathrm{~min})$ to $0.148 \AA^{-1}(\mathrm{t}=40 \mathrm{~min})$ (see Fig. 4E), which is indicative of the reassembly of the formed $\mathrm{NH}_{2}-\mathrm{HMS}$ particles. Besides, the average particle size of $\mathrm{NH}_{2}$-meso-silica/CTAB particles was reduced by $13.3 \%$ after the etching treatment (see Fig. 4F), which is also consistent with a reassembly of the particles.

In the literature, there are a number of approaches for the production of hollow structure silica materials including cationic surfactant assisted self-etching ${ }^{29}$, surface protected etching ${ }^{30}$, structural difference-based selective etching ${ }^{31}$, and Ostwald ripening. ${ }^{32}$ This paper proposes a very different approach to previous synthetic strategies where $\mathrm{NH}_{2}-\mathrm{HMS}$ is transformed from $\mathrm{NH}_{2}$-meso-silica spheres using surfactants in the mesopores and selective etching in alkaline solutions. This kind of transformation of $\mathrm{NH}_{2}$-meso-silica/CTAB to $\mathrm{NH}_{2}-\mathrm{HMS} / \mathrm{CTAB}$ is also very different from the Ostwald ripening process. ${ }^{32}$ With the Ostwald ripening process, particles located in the inner portions of the $\mathrm{SiO}_{2}$ sphere are generally smaller and those in the outer portions of the sphere are larger in size. To achieve thermodynamic equilibrium, the inner silica particles will be dissolved and regrow/deposit on the outer silica particles. ${ }^{33}$ Accordingly, the particle size increases after the transformation process, while with our synthetic procedure, the $\mathrm{NH}_{2}$-HMS particle size is essentially constant or decreases, as shown in Figures $4 \mathrm{C}$ and $\mathrm{F}$. Secondly, due to insufficient templating support from the CTAB molecules, Ostwald ripening and $\mathrm{SiO}_{2}$ condensation take place readily under identical etching conditions for $\mathrm{NH}_{2}$-mesosilica/CTAB synthesized at low CTAB concentrations. However, in our case, when the concentration of CTAB is decreased to $4 \mathrm{mmol} \mathrm{L}^{-1}$, the hollow structure of spheres disappears (see Fig. S1).

It is most likely that, when $\mathrm{NH}_{2}$-meso-silica/CTAB spheres are immersed in a $\mathrm{Na}_{2} \mathrm{CO}_{3}$ etchant, the $\mathrm{OH}^{-}$ions are rapidly exchanged with $\mathrm{Br}^{-}$ions in the CTAB molecules. More importantly, it would also appear that the concentration of $\mathrm{OH}^{-}$decreases from the core to the outer parts of the sphere because of the gradient of the CTAB concentrations in the interior 
parts $(d \rho / d r<0)$, as shown in Figure 5. Consequently, a high concentration of $\mathrm{OH}^{-}$will only be obtained in the core of the $\mathrm{NH}_{2}$-meso-silica/CTAB aggregate when the particles are immersed in a low concentration of alkaline solution. By contrast, when the particles are immersed in a high concentration of alkaline solution, both the interior and exterior portions of the $\mathrm{NH}_{2}$-mesosilica particles would be exposed to and attacked by high concentrations of $\mathrm{OH}^{-}$.

Based on the aforementioned hypotheses, a possible formation mechanism for $\mathrm{NH}_{2}-\mathrm{HMS}$ is proposed, as illustrated in Figure 6. After the addition of TEOS and APTES in the CTAB solution, the silica oligomers continuously assemble on the surface of the nucleus to form the $\mathrm{NH}_{2}$-meso-silica/CTAB spheres. When the $\mathrm{NH}_{2}$-meso-silica/CTAB spheres are immersed in a $\mathrm{Na}_{2} \mathrm{CO}_{3}$ solution, the ion exchange induced high concentration of $\mathrm{OH}^{-}$ions in the interior parts of the particles dissolve silicates to form the hollow structure. This explains why $\mathrm{NH}_{2}-$ mesosilica/CTAB spheres were dimensionally stable during etching in the lower $\mathrm{Na}_{2} \mathrm{CO}_{3}$ concentration range. Although the outer portions of the sphere are stable, ${ }^{20}$ the outer layers are dissolved by the $\mathrm{OH}^{-}$ions in the solution when the concentration of the etching agent reaches the threshold, resulting in decreased particle size. Nevertheless, the dissolved silicate colloids reassembled on the outer surface of the particle to maintain the initial sphere morphology. The proposed formation mechanism was verified by etching of $\mathrm{NH}_{2}$-meso-silica particles after the removal of CTAB (see Figs. 7A and 7B for TGA data on both pristine $\mathrm{NH}_{2}$-meso-silica and $\mathrm{NH}_{2}$-meso-silica/CTAB materials and TEM of pristine $\mathrm{NH}_{2}$-meso-silica, respectively). The mesoporous structure was substantially deteriorated and the surface of the sphere became roughened without the formation of hollow sphere structure (see Fig. 7C) when the $\mathrm{NH}_{2}-$ mesosilica particles without CTAB were etched in $0.2 \mathrm{~mol} \mathrm{~L}^{-1} \mathrm{Na}_{2} \mathrm{CO}_{3}$ solution. This is very different to the hollow sphere structure of $\mathrm{NH}_{2}$-meso-silica/CTAB particles formed under identical conditions (see Fig. 7D). Furthermore, by applying this synthetic strategy, hollow 
mesoporous silica were obtained from the transformation of mesoporous silica/CTAB spheres (see Fig. S3).

\subsection{Microstructure and properties of $\mathrm{PWA}-\mathrm{NH}_{2}-\mathrm{HMS}$ and composite membrane}

After PWA impregnation, the hollow and mesoporous structure in the shell of $\mathrm{PWA}^{-\mathrm{NH}_{2}-}$ HMS particles were clearly recognized in the bright field TEM mode, while a large amount of black dots of approximately $1-2 \mathrm{~nm}$ in size were confined in the mesoporous outer structure of the spheres (see Fig. 8A). The HAADF STEM image and EDS elemental mapping show the uniform distribution of tungsten (see Fig. 8C) and silicon (see Fig. 8D), indicating that the mesoporous channels of the $\mathrm{NH}_{2}$-HMS framework are filled with PWA, anchored to the mesoporous silica framework probably through hydrogen-bonding between the PWA and silica. ${ }^{34}$ The reduced peak intensity in synchrotron SAXS data (see Fig. S3A) and decrease in BET surface area and pore size (see Fig. S3B) of the $\mathrm{NH}_{2}$-HMS matrix after PWA impregnation also confirm the presence of PWA within the $\mathrm{NH}_{2}-\mathrm{HMS}$ structure. The pore size of the $\mathrm{NH}_{2}$-HMS particles was $4.8 \mathrm{~nm}$ as calculated from Barrett-Joyner-Halenda adsorption method. After PWA impregnation, the pore size decreased to $4.3 \mathrm{~nm}$ (Fig. S3B).

After the blending of PWA-NH $2-H M S$ particles with PES-PVP in solution, homogeneous composite membranes were obtained with a PWA- $\mathrm{NH}_{2}-\mathrm{HMS}$ loading up to $15 \mathrm{wt} \%$, as evidenced from the cross-sectional SEM images (Fig. 9). The pristine and dry composite membrane has a thickness of $50-80 \mu \mathrm{m}$. Thermogravimetric analysis was employed to confirm the composition of PWA- $\mathrm{NH}_{2}-\mathrm{HMS}$ after membrane casting and further demonstrates that the thermo-oxidative stability of the base material has been improved (see Fig. S4). The composite membranes were subsequently equilibrated in $85 \mathrm{wt} \% \mathrm{H}_{3} \mathrm{PO}_{4}$ at room temperature. The PA uptake was determined gravimetrically relative to the weight of the dry membrane, and was found to decrease gradually with increasing PWA- $\mathrm{NH}_{2}-\mathrm{HMS}$ loading (see Table 1), which is consistent with the concomitant influence of silica materials on the PA uptake of 
PA/PES-PVP composite membranes. ${ }^{11}$ The PA uptake of the pristine PES-PVP composite membrane was $303 \mathrm{wt} \%$, corresponding to about 4.9 PA per PVP repeat unit, as compared with $288 \mathrm{wt} \%$ for the composite with a PWA-NH $2-\mathrm{HMS}$ loading of $15 \mathrm{wt} \%$. The elastic modulus was enhanced with increasing PWA-NH $2-H M S$ loading (see Fig. 10), which is likely due to interactions between the filler material and the polymer matrix. For example, the elastic modulus of PA/PES-PVP membrane was $16 \mathrm{MPa}$ as compared with $28 \mathrm{MPa}$ for the membrane with a PWA-NH$-\mathrm{NMS}$ loading of $15 \mathrm{wt} \%$. However the strain of the composite membrane decreased with the increase of PWA-NH 2 -HMS loading (Fig. 10A). The mechanical properties of the composite membrane are given in Table 1.

\subsection{Proton conductivity and cell performance}

${ }^{1} \mathrm{H}$ static NMR spectroscopy clearly shows that, after the addition of PWA, the PA/PESPVP composite membrane showed a higher mobile proton content of $75.3 \%$ than that of a pristine PA/PES-PVP membrane (67.9\%) (see Fig. 11A). Moreover, the former membrane showed narrower ${ }^{1} \mathrm{H}$ NMR lines than the latter one, suggesting a higher proton mobility. Besides, the ${ }^{1} \mathrm{H}$ MAS NMR linewidth analysis presented in Figure 11B shows that, in PWAPES-PVP sample, the OH peak on the pyridine ring is narrower than the pristine PES-PVP, suggesting more mobile polymer chain in this sample. The NMR data are indicative of PWA increasing the proton conductivity of PA/PES-PVP, which is confirmed by the following electrochemical studies.

The in-situ proton conductivity of the PES-PVP based composite membranes with various fillers at different loadings was measured at various temperatures without humidification of the feed gases (see Fig. 11C). The pristine PA/PES-PVP membrane showed a proton conductivity of $7.8 \times 10^{-2} \mathrm{~S} \mathrm{~cm}^{-1}$ at $120^{\circ} \mathrm{C}$, which was increased to $1.14 \times 10^{-1} \mathrm{~S} \mathrm{~cm}^{-1}$ at $180{ }^{\circ} \mathrm{C}$. Furthermore, the proton conductivity of the hybrid nanocomposite membrane increased with the addition of $\mathrm{NH}_{2}$-HMS or PWA-NH 2 -HMS. The best results were obtained on a hybrid membrane with 10 
wt $\%$ PWA-NH $2-\mathrm{HMS}$, showing the highest proton conductivity of $1.75 \times 10^{-1} \mathrm{~S} \mathrm{~cm}^{-1}$ at 180 ${ }^{\circ} \mathrm{C}$ without humidification, which is $35 \%$ higher than that of membrane with $10 \mathrm{wt} \% \mathrm{NH}_{2}$ HMS fillers under similar conditions $\left(1.29 \times 10^{-1} \mathrm{~S} \mathrm{~cm}^{-1}\right)$. This is most likely due to a significant contribution from PWA in the $\mathrm{NH}_{2}$-HMS to the proton conductivity. ${ }^{35}$ The single cell performance of the PA doped PES-PVP composite membrane was evaluated at different temperatures. The peak power density of the cell with the PA/PES-PVP membrane was 249.1

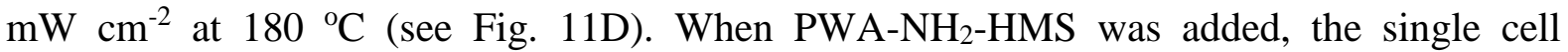
performance increased due to improvements with the proton conductivity. The highest cell performance was obtained on the PES-PVP composite membrane with $10 \mathrm{wt} \% \mathrm{PWA}^{-\mathrm{NH}_{2}-}$ HMS, reaching a peak power density $420 \mathrm{~mW} \mathrm{~cm}^{-2}$ at $180{ }^{\circ} \mathrm{C}$. The enhancement in cell performance is clearly due to the positive influence of PWA on the proton conductivity and facilitated proton diffusion in the mesopores of $\mathrm{NH}_{2}-\mathrm{HMS}$.

Fuel cell durability studies were conducted at $200{ }^{\circ} \mathrm{C}$ under a current load of $200 \mathrm{~mA} \mathrm{~cm}^{-}$ ${ }^{2}$, using the PA/PES-PVP composite membranes with PWA- $\mathrm{NH}_{2}-\mathrm{HMS}$ loadings of 0,5 , and $15 \%$, as shown in Figure 12. The cell voltage of pristine PES-PVP composite membrane sharply diminishes from $0.62 \mathrm{~V}$ to $0.36 \mathrm{~V}$ after a 1300 min test. This substantial degradation in performance durability is most likely due to the reduced proton conductivity associated with the acid leaching of PA/PES-PVP membranes at an elevated operational temperature of 200 ${ }^{\circ} \mathrm{C} .{ }^{36}$ This high temperature might also cause a loss in mechanical strength of the PA/PES-PVP membrane, degrading the cell performance. By adding $\mathrm{PWA}-\mathrm{NH}_{2}-\mathrm{HMS}$ to the membrane, the durability of the cell is significantly improved, despite that the calculated glass transition temperature of PES-PVP with weight ratio of $3: 7$ of $190{ }^{\circ} \mathrm{C},{ }^{37}$ which is lower than the fuel cell operational temperature. This apparent anomaly is probably due to the interactions between the $\mathrm{O}$ and $\mathrm{N}$ atoms in PVP with PA and PWA, respectively (see Fig. S5). ${ }^{38-40}$ The slightly lower cell voltage with a composite membrane containing $15 \mathrm{wt} \% \mathrm{PWA}-\mathrm{NH}_{2}-\mathrm{HMS}$ in comparison 
with the one comprising $5 \mathrm{wt} \%$ PWA- $\mathrm{NH}_{2}-\mathrm{HMS}$ is probably due to the lower proton conductivity of the membrane. Nevertheless, the cell with a membrane containing $15 \mathrm{wt} \%$ PWA-NH 2 -HMS showed significantly enhanced durability compared with cells fitted out with membranes of lower PWA- $\mathrm{NH}_{2}$-HMS content. The significantly enhanced durability of cells with PWA-NH $\mathrm{N}_{2}-\mathrm{HMS} / \mathrm{PES}-\mathrm{PVP}$ nanocomposite membranes is most likely attributable to the increased thermal stability and mechanical strength of membranes comprising inorganic fillers and the likely formation of an in situ phosphosilicate proton conducting phase ${ }^{24}$ in the composite membranes.

\section{Conclusions}

The $\mathrm{NH}_{2}$-HMS material has been successfully synthesized via a new and facile strategy of ion exchange induced selective etching derived from $\mathrm{NH}_{2}$-meso-silica/CTAB spheres. More importantly, the strategy has been verified by the successful fabrication of hollow mesoporous silica by simple removal of amino silane in the solution. Addition of PWA impregnated $\mathrm{NH}_{2}$ HMS (PWA-NH $\mathrm{N}_{2}-\mathrm{HMS}$ ) significantly improved the properties of the PES-PVP membranes. Best proton conductivity and performance was obtained on cells with PA/PES-PVP composite membrane with $10 \mathrm{wt} \%$ PWA-NH $2-\mathrm{HMS}$, achieving a high proton conductivity up to $1.75 \times$ $10^{-1} \mathrm{~S} \mathrm{~cm}^{-1}$ and maximum power density of $420 \mathrm{~mW} \mathrm{~cm}^{-2}$ at $180{ }^{\circ} \mathrm{C}$ without external humidification. Moreover, increasing the loading of PWA-NH $\mathrm{N}_{2}-\mathrm{HMS}$ in PES-PVP to $15 \mathrm{wt} \%$, a significantly enhanced fuel cell durability at $200{ }^{\circ} \mathrm{C}$ was obtained. The results demonstrate the feasibility of an ion exchange induced selective etching technique for the synthesis of $\mathrm{NH}_{2}-$ HMS nanoparticles along with the promising application of the PWA-functionalized $\mathrm{NH}_{2}$ HMS material in nanocomposite membranes for PEMFCs with high power output and high durability at elevated high temperatures.

\section{Acknowledgements}


This work is financially supported by Australia Research Council under the Discovery Project Scheme (project number: DP150102025 and DP150102044) and the ForskE1 program (Dura PEMIII). The authors greatly appreciate the help from Dr. Kongfa Chen and Dr. Jian Pan in Curtin University for the SEM characterization and the production of schematics included in this manuscript. We also thank Dr. Martin Saunders at the Centre for Microscopy, Characterization \& Analysis at the University of Western Australia for assistance with the STEM study. The synchrotron SAXS was carried out on the SAXS beamline at the Australian Synchrotron, Victoria Australia, with the assistance of Drs. Stephen Mudie and Nigel Kirby.

Supporting Information. NMR, TEM, SAXS, BET, TGA and ATR-FTIR of PES-PVP composite membranes with different loadings of PWA- $\mathrm{NH}_{2}-\mathrm{HMS}$.

\section{References}

1. Li, Y. H.; Li, N.; Pan, W.; Yu, Z. Z.; Yang, L. M.; Tang, B., Hollow Mesoporous Silica Nanoparticles with Tunable Structures for Controlled Drug Delivery. ACS Appl. Mater. Interfaces 2017, 9 (3), 2123-2129.

2. Zargar, M.; Hartanto, Y.; Jin, B.; Dai, S., Hollow Mesoporous Silica Nanoparticles: A Peculiar Structure for Thin Film Nanocomposite Membranes. J. Membr. Sci. 2016, 519, 1-10.

3. Dou, J.; Zeng, H. C., Targeted Synthesis of Silicomolybdic Acid (Keggin Acid) inside Mesoporous Silica Hollow Spheres for Friedel-Crafts Alkylation. J. Am. Chem. Soc. 2012, 134 (39), 16235-16246.

4. Zhao, Y. N.; Yang, H.; Wu, H. Y.; Jiang, Z. Y., Enhanced Proton Conductivity of Hybrid Membranes by Incorporating Phosphorylated Hollow Mesoporous Silica Submicrospheres. J. Membr. Sci. 2014, 469, 418-427.

5. El-Toni, A. M.; Habila, M. A.; Ibrahim, M. A.; Labis, J. P.; Alothman, Z. A., Simple and Facile Synthesis of Amino Functionalized Hollow Core-Mesoporous Shell Silica Spheres Using Anionic Surfactant for Pb(li), Cd(li), and Zn(li) Adsorption and Recovery. Chem. Eng. J. 2014, 251, 441-451.

6. Meka, A. K.; Abbaraju, P. L.; Song, H.; Xu, C.; Zhang, J.; Zhang, H. W.; Yu, M. H.; Yu, C. Z., A Vesicle Supra-Assembly Approach to Synthesize Amine-Functionalized Hollow Dendritic Mesoporous Silica Nanospheres for Protein Delivery. Small 2016, 12 (37), 5169-5177.

7. Yokoi, T.; Kubota, Y.; Tatsumi, T., Amino-Functionalized Mesoporous Silica as Base Catalyst and Adsorbent. Appl. Catal. A Gen. 2012, 421-422, 14-37. 
8. Yin, Y. H.; Deng, W. Y.; Wang, H. Y.; Li, A. P.; Wang, C. B.; Jiang, Z. Y.; Wu, H., Fabrication of Hybrid Membranes by Incorporating Acid-Base Pair Functionalized Hollow Mesoporous Silica for Enhanced Proton Conductivity. J. Mater. Chem. A 2015, 3 (31), 16079-16088.

9. Li, N.; Yu, Z.; Pan, W.; Han, Y.; Zhang, T.; Tang, B., A Near-Infrared Light-Triggered Nanocarrier with Reversible DNA Valves for Intracellular Controlled Release. Adv. Funct. Mater. 2013, 23 (18), 2255-2262.

10. Yu, Z.; Li, N.; Zheng, P.; Pan, W.; Tang, B., Temperature-Responsive DNA-Gated Nanocarriers for Intracellular Controlled Release. Chem. Commun. 2014, 50 (26), 3494-3497. 11. Zhang, J.; Lu, S.; Zhu, H.; Chen, K.; Xiang, Y.; Liu, J.; Forsyth, M.; Jiang, S. P., AminoFunctionalized Mesoporous Silica Based Polyethersulfone-Polyvinylpyrrolidone Composite Membranes for Elevated Temperature Proton Exchange Membrane Fuel Cells. RSC Advances 2016, 6 (89), 86575-86585.

12. Danon, A.; Stair, P. C.; Weitz, E., FTIR Study of Co2 Adsorption on Amine-Grafted Sba15: Elucidation of Adsorbed Species. J. Phys. Chem. C 2011, 115 (23), 11540-11549.

13. Suteewong, T.; Sai, H.; Cohen, R.; Wang, S.; Bradbury, M.; Baird, B.; Gruner, S. M.; Wiesner, U., Highly Aminated Mesoporous Silica Nanoparticles with Cubic Pore Structure. J. Am. Chem. Soc. 2011, 133 (2), 172-175.

14. Hoffmann, F.; Cornelius, M.; Morell, J.; Fröba, M., Silica-Based Mesoporous OrganicInorganic Hybrid Materials. Angew. Chem. Int. Ed. 2006, 45 (20), 3216-3251.

15. Gao, J.; Zhang, X.; Lu, Y.; Liu, S.; Liu, J., Selective Functionalization of Hollow Nanospheres with Acid and Base Groups for Cascade Reactions. Chem. Eur. J. 2015, 21 (20), 7403-7407.

16. Meka, A. K.; Abbaraju, P. L.; Song, H.; Xu, C.; Zhang, J.; Zhang, H.; Yu, M.; Yu, C., A Vesicle Supra-Assembly Approach to Synthesize Amine-Functionalized Hollow Dendritic Mesoporous Silica Nanospheres for Protein Delivery. Small 2016, 12 (37), 5169-5177.

17. Hao, N.; Jayawardana, K. W.; Chen, X.; Yan, M., One-Step Synthesis of AmineFunctionalized Hollow Mesoporous Silica Nanoparticles as Efficient Antibacterial and Anticancer Materials. ACS Appl. Mater. Interfaces 2015, 7 (2), 1040-1045.

18. Wang, X.; Feng, J.; Bai, Y.; Zhang, Q.; Yin, Y., Synthesis, Properties, and Applications of Hollow Micro-/Nanostructures. Chem. Rev. 2016, 116 (18), 10983-11060.

19. Zhang, T.; Ge, J.; Hu, Y.; Zhang, Q.; Aloni, S.; Yin, Y., Formation of Hollow Silica Colloids through a Spontaneous Dissolution-Regrowth Process. Angew. Chem. Int. Ed. 2008, 47 (31), 5806-5811.

20. Teng, Z.; Wang, S.; Su, X.; Chen, G.; Liu, Y.; Luo, Z.; Luo, W.; Tang, Y.; Ju, H.; Zhao, D.; Lu, G., Facile Synthesis of Yolk-Shell Structured Inorganic-Organic Hybrid Spheres with Ordered Radial Mesochannels. Adv. Mater. 2014, 26 (22), 3741-3747.

21. Li, M.-Q.; Shao, Z.-G.; Scott, K., A High Conductivity Cs2.5h0.5pmo12o40/Polybenzimidazole (Pbi)/H3po4 Composite Membrane for ProtonExchange Membrane Fuel Cells Ope-Rating at High Temperature. J. Power Sources 2008, 183 (1), 69-75.

22. Asensio, J. A.; Borrós, S.; Gómez-Romero, P., Enhanced Conductivity in PolyanionContaining Polybenzimidazoles. Improved Materials for Proton-Exchange Membranes and Pem Fuel Cells. Electrochem. Commun. 2003, 5 (11), 967-972.

23. Gomez-Romero, P.; Asensio, J. A.; Borros, S., Hybrid Proton-Conducting Membranes for Polymer Electrolyte Fuel Cells Phosphomolybdic Acid Doped Poly(2,5-Benzimidazole)(Abpbi-H3pmo12o40). Electrochim. Acta 2005, 50 (24), 4715-4720. 
24. Aili, D.; Zhang, J.; Dalsgaard Jakobsen, M. T.; Zhu, H.; Yang, T.; Liu, J.; Forsyth, M.; Pan, C.; Jensen, J. O.; Cleemann, L. N.; Jiang, S. P.; Li, Q., Exceptional Durability Enhancement of $\mathrm{Pa} / \mathrm{Pbi}$ Based Polymer Electrolyte Membrane Fuel Cells for High Temperature Operation at 200 [Degree]C. J. Mater. Chem. A 2016, 4 (11), 4019-4024.

25. Lu, S.; Wang, D.; Jiang, S. P.; Xiang, Y.; Lu, J.; Zeng, J., HPW/MCM-41 Phosphotungstic Acid/Mesoporous Silica Composites as Novel Proton-Exchange Membranes for ElevatedTemperature Fuel Cells. Adv. Mater. 2010, 22 (9), 971-976.

26. Blin, J. L.; Gérardin, C.; Rodehüser, L.; Selve, C.; Stébé, M. J., Influence of Alkyl Peptidoamines on the Structure of Functionalized Mesoporous Silica. Chem. Mater. 2004, 16 (24), 5071-5080.

27. Suteewong, T.; Sai, H.; Bradbury, M.; Estroff, L. A.; Gruner, S. M.; Wiesner, U., Synthesis and Formation Mechanism of Aminated Mesoporous Silica Nanoparticles. Chem. Mater. 2012, 24 (20), 3895-3905.

28. Teng, Z.; Su, X.; Zheng, Y.; Sun, J.; Chen, G.; Tian, C.; Wang, J.; Li, H.; Zhao, Y.; Lu, G., Mesoporous Silica Hollow Spheres with Ordered Radial Mesochannels by a Spontaneous SelfTransformation Approach. Chem. Mater. 2013, 25 (1), 98-105.

29. Fang, X.; Chen, C.; Liu, Z.; Liu, P.; Zheng, N., A Cationic Surfactant Assisted Selective Etching Strategy to Hollow Mesoporous Silica Spheres. Nanoscale 2011, 3 (4), 1632-1639.

30. Zhang, Q.; Zhang, T.; Ge, J.; Yin, Y., Permeable Silica Shell through Surface-Protected Etching. Nano Lett. 2008, 8 (9), 2867-2871.

31. Chen, Y.; Chen, H.; Guo, L.; He, Q.; Chen, F.; Zhou, J.; Feng, J.; Shi, J., Hollow/RattleType Mesoporous Nanostructures by a Structural Difference-Based Selective Etching Strategy. ACS Nano 2010, 4 (1), 529-539.

32. Wang, D. P.; Zeng, H. C., Creation of Interior Space, Architecture of Shell Structure, and Encapsulation of Functional Materials for Mesoporous SiO2 Spheres. Chem. Mater. 2011, 23 (22), 4886-4899.

33. Zeng, H. C., Synthesis and Self-Assembly of Complex Hollow Materials. J. Mater. Chem. 2011, 21 (21), 7511-7526.

34. Shiju, N. R.; Alberts, A. H.; Khalid, S.; Brown, D. R.; Rothenberg, G., Mesoporous Silica with Site-Isolated Amine and Phosphotungstic Acid Groups: A Solid Catalyst with Tunable Antagonistic Functions for One-Pot Tandem Reactions. Angew. Chem. Int. Ed. 2011, 50 (41), 9615-9619.

35. Zhou, Y. H.; Yang, J.; Su, H. B.; Zeng, J.; Jiang, S. P.; Goddard, W. A., Insight into Proton Transfer in Phosphotungstic Acid Functionalized Mesoporous Silica-Based Proton Exchange Membrane Fuel Cells. J. Am. Chem. Soc. 2014, 136 (13), 4954-4964.

36. Zeng, J.; He, B.; Lamb, K.; De Marco, R.; Shen, P. K.; Jiang, S. P., Anhydrous Phosphoric Acid Functionalized Sintered Mesoporous Silica Nanocomposite Proton Exchange Membranes for Fuel Cells. ACS Appl. Mater. Interfaces 2013, 5 (21), 11240-11248.

37. Xu, X.; Wang, H.; Lu, S.; Guo, Z.; Rao, S.; Xiu, R.; Xiang, Y., A Novel Phosphoric Acid Doped Poly(Ethersulphone)-Poly(Vinyl Pyrrolidone) Blend Membrane for High-Temperature Proton Exchange Membrane Fuel Cells. J. Power Sources 2015, 286, 458-463.

38. Szaraz, I.; Forsling, W., Interaction between a Capacitor Electrolyte and GammaAluminum Oxide Studied by Fourier Transform Infrared Spectroscopy. Appl Spectrosc 2003, $57(6), 622-7$.

39. Lu, S.; Xu, X.; Zhang, J.; Peng, S.; Liang, D.; Wang, H.; Xiang, Y., A Self-Anchored Phosphotungstic Acid Hybrid Proton Exchange Membrane Achieved Via One-Step Synthesis. Adv. Energy Mater. 2014, 4 (17), 1400842. 
40. Asensio, J. A.; Borrós, S.; Gómez-Romero, P., Proton-Conducting Polymers Based on Benzimidazoles and Sulfonated Benzimidazoles. J. Polym. Sci. Part A Polym. Chem. 2002, 40 (21), 3703-3710. 
Table 1 Properties of the PA doped PES-PVP composite membranes with various loading of PWA$\mathrm{NH}_{2}$-HMS fillers.

\begin{tabular}{|c|c|c|c|c|c|c|c|c|c|}
\hline \multirow{2}{*}{$\begin{array}{l}\text { Inorganic } \\
\text { filers }\end{array}$} & \multirow{2}{*}{$\begin{array}{l}\text { Loading, } \\
\%\end{array}$} & \multirow{2}{*}{$\begin{array}{l}\text { PA } \\
\text { uptake, } \\
\text { wt } \%\end{array}$} & \multirow{2}{*}{$\begin{array}{l}\text { Volume } \\
\text { swelling, } \\
\%\end{array}$} & \multirow{2}{*}{$\begin{array}{l}\text { PA per } \\
\text { Unit }\end{array}$} & \multirow{2}{*}{$\begin{array}{l}\text { Elastic } \\
\text { modulus, } \\
\mathrm{MPa}\end{array}$} & \multicolumn{4}{|c|}{ Proton conductivity, $\times 10^{-1} \mathrm{~S} \mathrm{~cm}^{-1}$} \\
\hline & & & & & & $120^{\circ} \mathrm{C}$ & $140{ }^{\circ} \mathrm{C}$ & $160^{\circ} \mathrm{C}$ & $180^{\circ} \mathrm{C}$ \\
\hline \multirow{4}{*}{$\begin{array}{l}\text { PWA-NH }_{2-} \\
\text { HMS }\end{array}$} & 0 & $303 \pm 19$ & $213 \pm 4$ & $4.9 \pm 0.3$ & $16 \pm 4$ & 0.78 & 0.92 & 1.06 & 1.14 \\
\hline & 5.0 & $304 \pm 11$ & $343 \pm 37$ & $4.9 \pm 0.2$ & $30 \pm 13$ & 1.15 & 1.39 & 1.47 & 1.61 \\
\hline & 10.0 & $294 \pm 10$ & $265 \pm 27$ & $4.8 \pm 0.2$ & $23 \pm 10$ & 1.34 & 1.52 & 1.64 & 1.75 \\
\hline & 15.0 & $288 \pm 9$ & $223 \pm 15$ & $4.7 \pm 0.1$ & $28 \pm 13$ & 1.08 & 1.33 & 1.44 & 1.55 \\
\hline $\mathrm{NH}_{2}$-HMS & 10.0 & $278 \pm 12$ & $179 \pm 14$ & $4.5 \pm 0.2$ & - & 0.94 & 1.03 & 1.18 & 1.29 \\
\hline
\end{tabular}




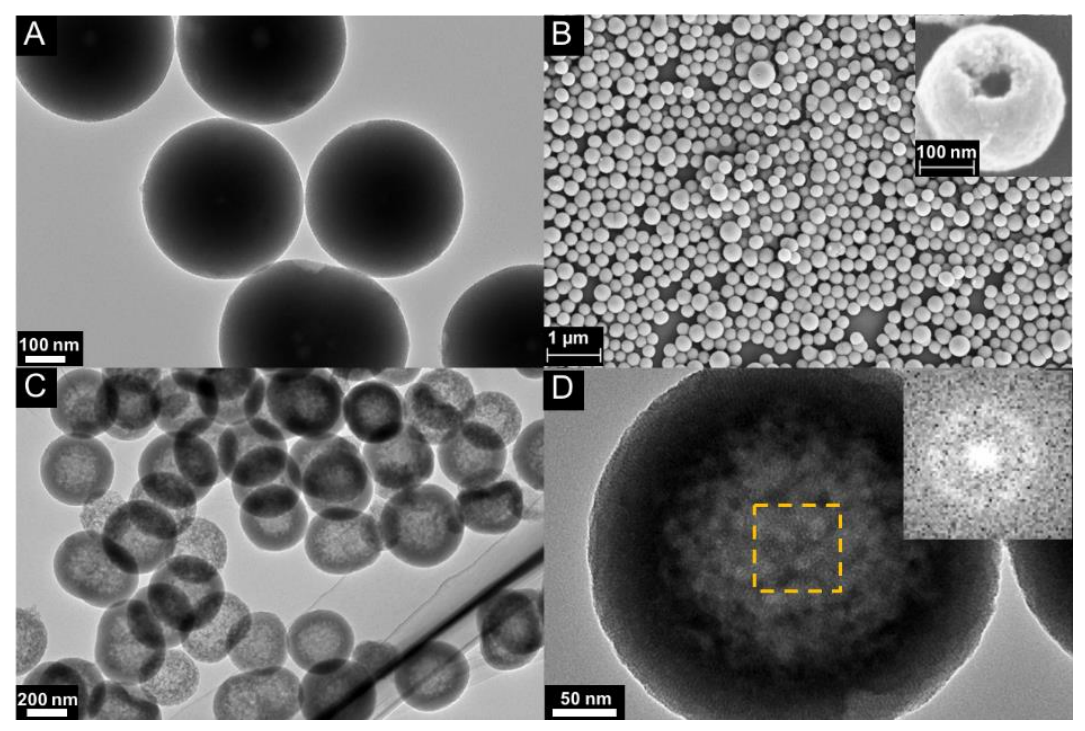

Figure 1. (A) TEM image of $\mathrm{NH}_{2}$-meso-silica nanoparticles; (B) and (C) SEM and TEM images for the $\mathrm{NH}_{2}-\mathrm{HMS}$ nanoparticles, respectively and (D) An enlarged TEM image for a single $\mathrm{NH}_{2}$-HMS nanoparticle. 

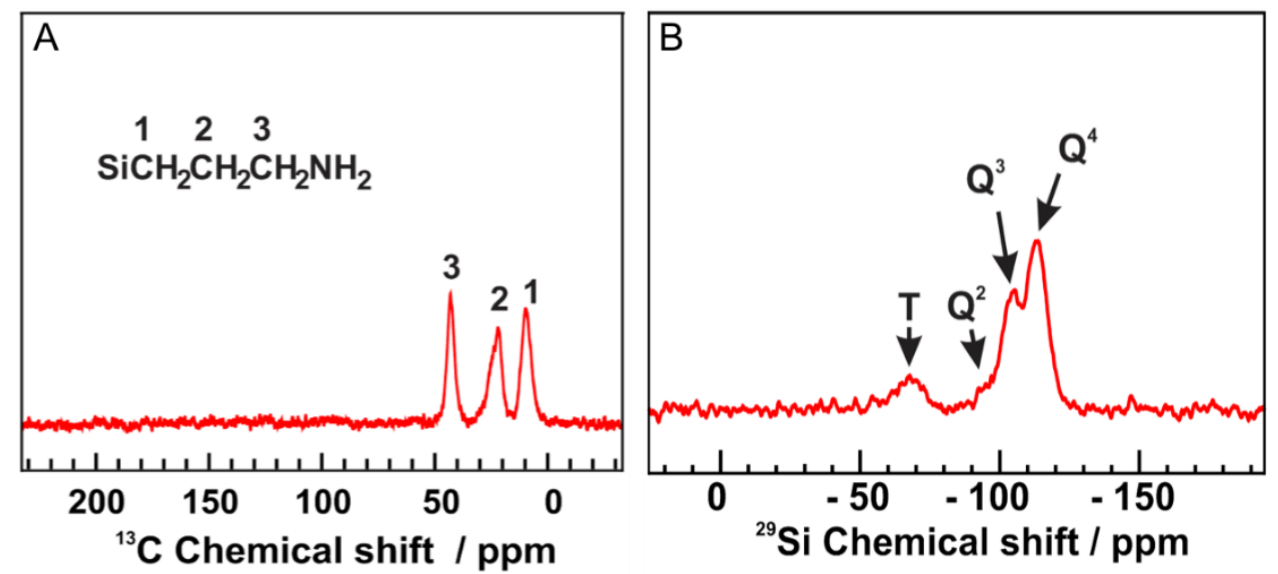

Figure 2. (A) ${ }^{13} \mathrm{C}$ NMR chemical shift and (B) ${ }^{29} \mathrm{Si}$ NMR for the $\mathrm{NH}_{2}-\mathrm{HMS}$ nanoparticles. Fabrication conditions: 10 mol\% APTES. Etching condition: $0.3 \mathrm{~mol} \mathrm{~L}^{-1} \mathrm{Na}_{2} \mathrm{CO}_{3}$ at $60{ }^{\circ} \mathrm{C}$ for 2h. CTAB surfactant was removed by a $\mathrm{EtOH} / \mathrm{HCl}$ extraction. 

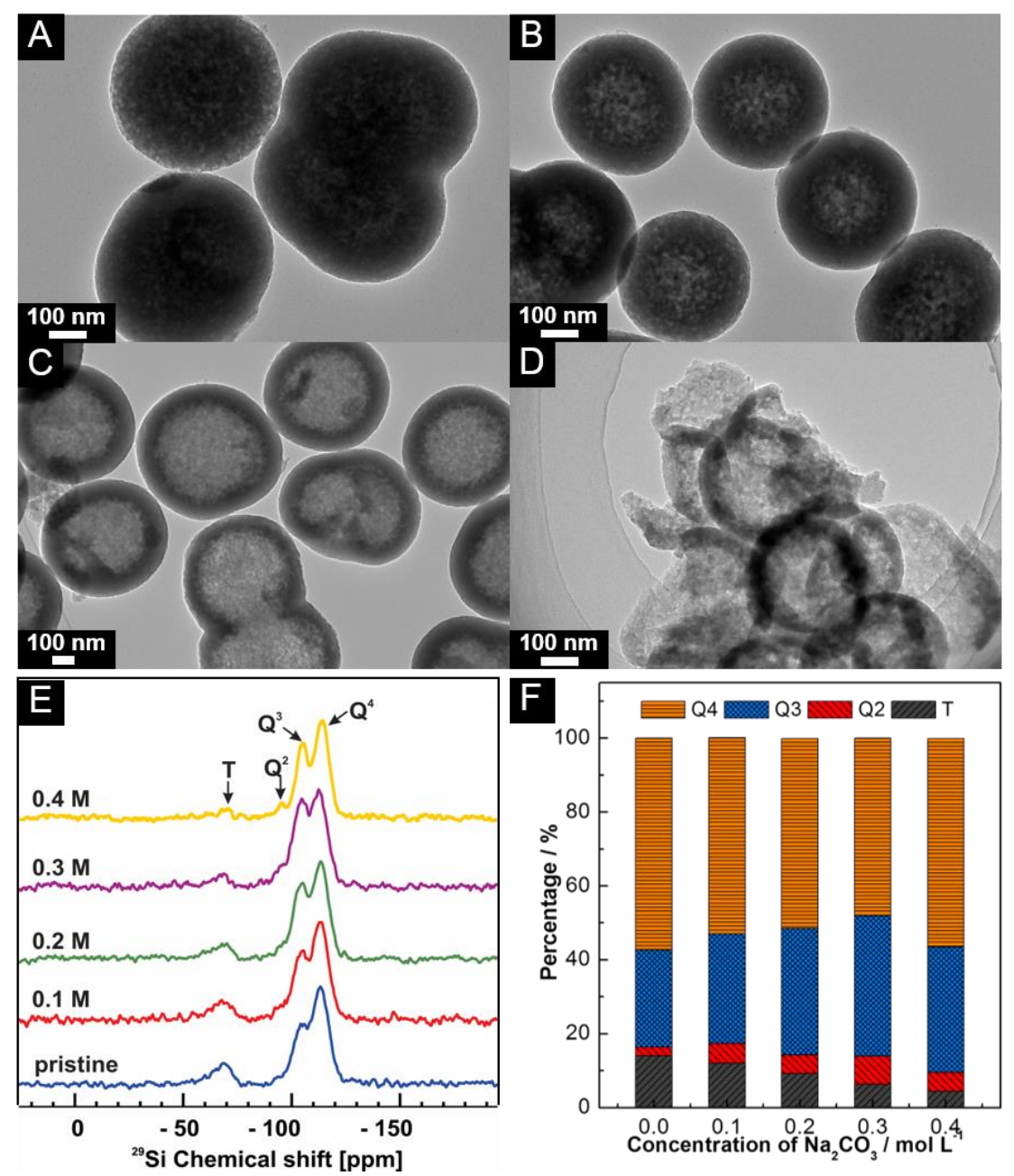

Figure 3. TEM images of $\mathrm{NH}_{2}$-meso-silica/CTAB treated by $\mathrm{Na}_{2} \mathrm{CO}_{3}$ solutions at $60{ }^{\circ} \mathrm{C}$ for 2 $\mathrm{h}$ with different concentrations: (A) $0.1 \mathrm{~mol} \mathrm{~L}^{-1}$; (B) $0.2 \mathrm{~mol} \mathrm{~L}^{-1}$; (C) $0.3 \mathrm{~mol} \mathrm{~L}^{-1}$; (D) $0.4 \mathrm{~mol}$ $\mathrm{L}^{-1}$; (E) the corresponding ${ }^{29} \mathrm{Si}$ MAS NMR spectra and (F) quantitative ${ }^{29} \mathrm{Si}$ MAS NMR analysis for the products. The CTAB surfactant in the final products was removed by a reflux treatment in $\mathrm{EtOH} / \mathrm{HCl}$ at $80{ }^{\circ} \mathrm{C}$ for $3 \mathrm{~h}$. 

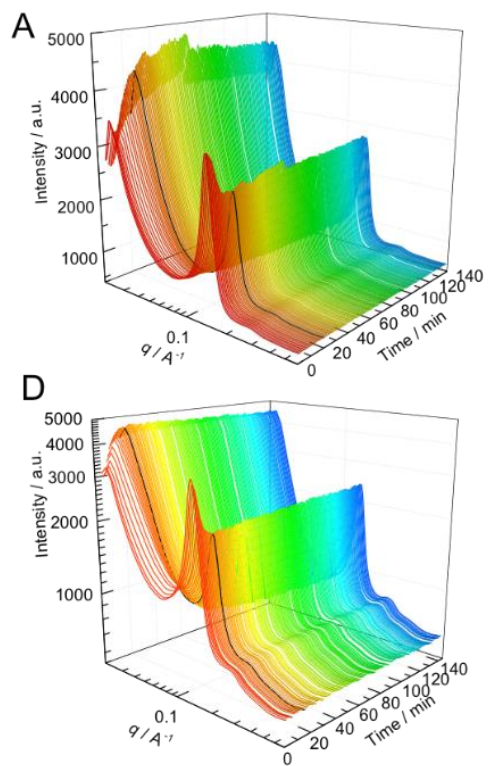

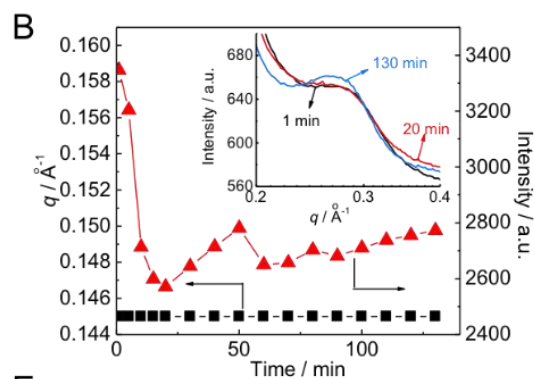

E

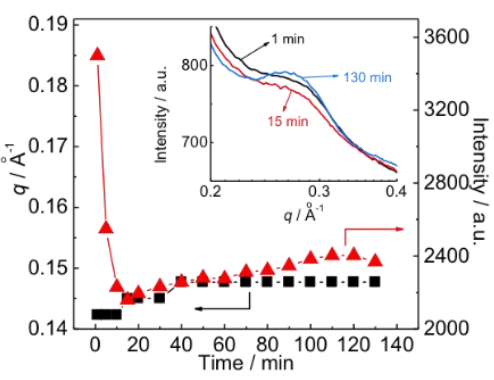

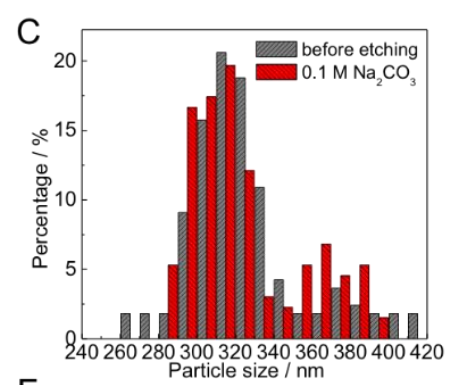

$\mathrm{F}$

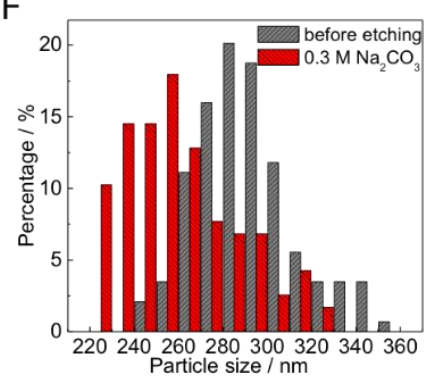

Figure 4. The in situ synchrotron SAXS profiles for the etching of $\mathrm{NH}_{2}$-meso-silica/CTAB at different $\mathrm{Na}_{2} \mathrm{CO}_{3}$ concentrations (A) $0.1 \mathrm{~mol} \mathrm{~L}^{-1}$ and (D) $0.3 \mathrm{~mol} \mathrm{~L} \mathrm{~L}^{-1} \mathrm{Na}_{2} \mathrm{CO}_{3}$. The corresponding changes of the peak position and intensity for the samples etched at $0.1 \mathrm{~mol} \mathrm{~L}^{-1}$ and $0.3 \mathrm{~mol} \mathrm{~L}^{-1}$, respectively, are given in (B) and (E), and the particles size distribution of the two samples after the etching treatment are given in $(\mathrm{C})$ and $(\mathrm{F})$. 


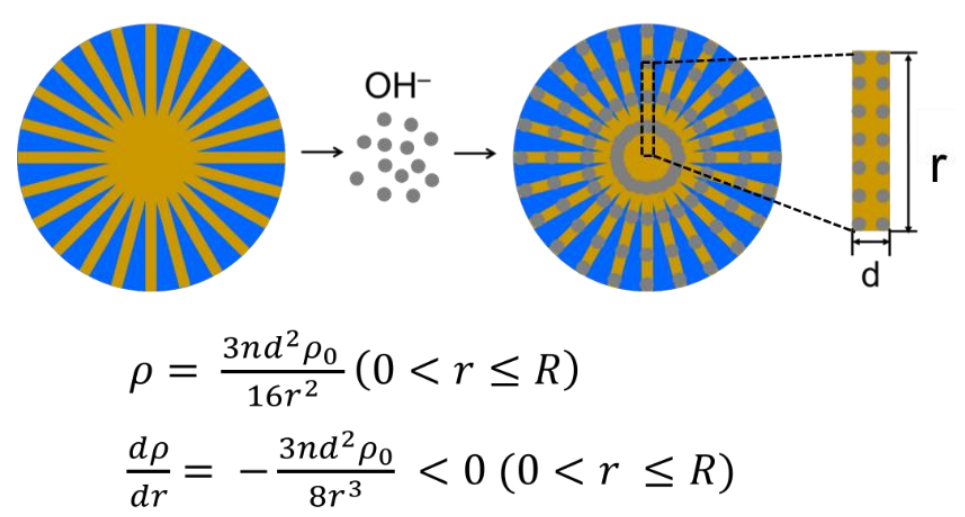

Figure 5. Schematic depiction of the $\mathrm{NH}_{2}$-meso-silica/CTAB particle after the $\mathrm{OH}^{-}$ions exchange via CTAB molecules, where $\rho$ and $\rho_{0}$ is the density of $\mathrm{OH}^{-}$ions and CTAB in the mesopores, respectively, $n$ is the number of mesopores in the sphere, $d$ is the diameter of a mesopores, $r$ is the radius started from the centre of the sphere, and $R$ is the radius of the $\mathrm{NH}_{2}-$ meso-silica/CTAB. 

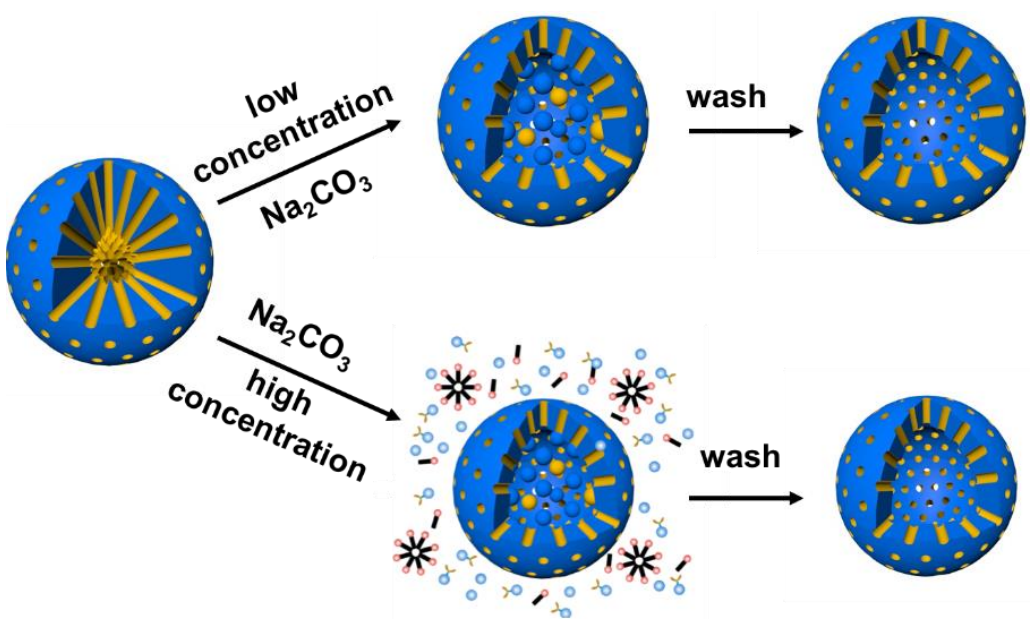

Figure 6. Scheme for the fabrication of $\mathrm{NH}_{2}-\mathrm{HMS}$ nanoparticles induced by ion exchange. 

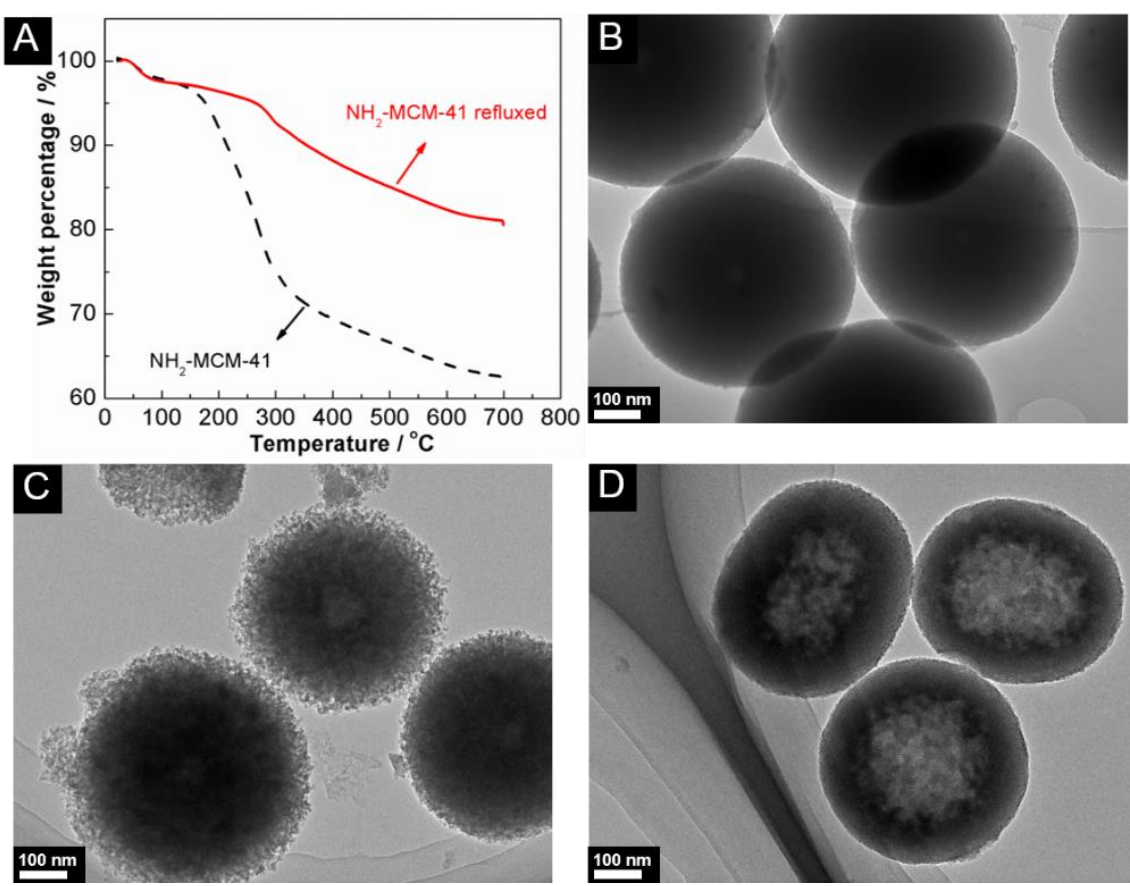

Figure 7. (A) TGA profiles of $\mathrm{NH}_{2}$-meso-silica/CTAB and $\mathrm{NH}_{2}$-meso-silica spheres, TEM images of (B) pristine $\mathrm{NH}_{2}$-meso-silica/CTAB, (C) $\mathrm{NH}_{2}$-meso-silica after removal of CTAB etched at $0.2 \mathrm{~mol} \mathrm{~L}^{-1} \mathrm{Na}_{2} \mathrm{CO}_{3}$ at $60{ }^{\circ} \mathrm{C}$ for $2 \mathrm{~h}$ and (D) $\mathrm{NH}_{2}$-meso-silica/CTAB materials etched under the same conditions. 


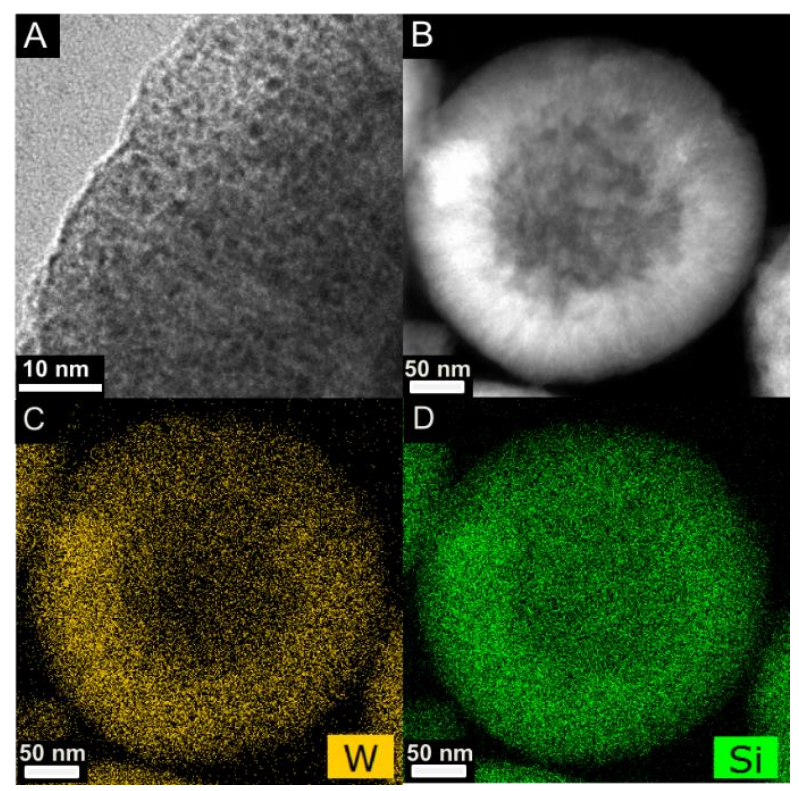

Figure 8. (A) and (B) Bright field and HAADF STEM images for a single PWA-NH $-\mathrm{HMS}$ nanoparticle, and elemental mapping for (C) W and (D) Si. 


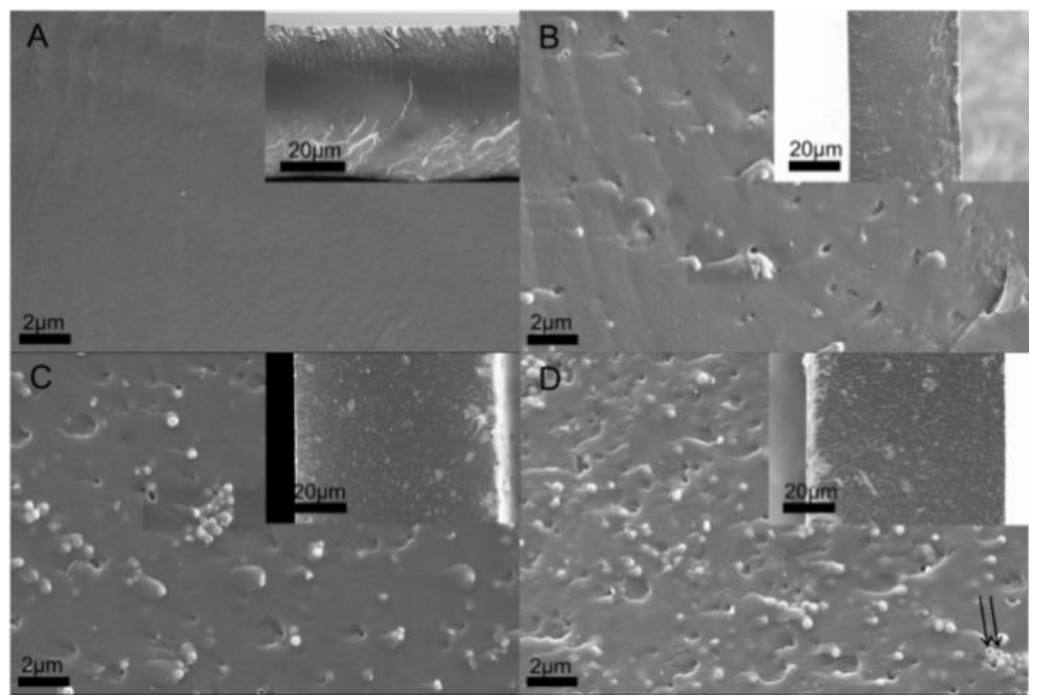

Figure 9. Cross sectional SEM images of the PES-PVP composite membranes with various

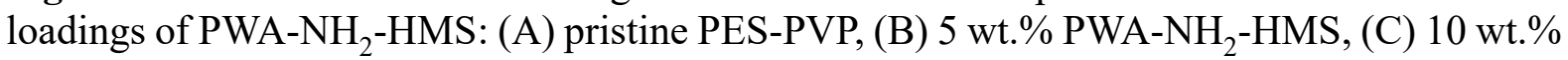
PWA- $\mathrm{NH}_{2}-\mathrm{HMS}$, and (D) 15 wt.\% PWA- $\mathrm{NH}_{2}-\mathrm{HMS}$. Inset images are the pictures of the corresponding membranes at a lower magnification. 

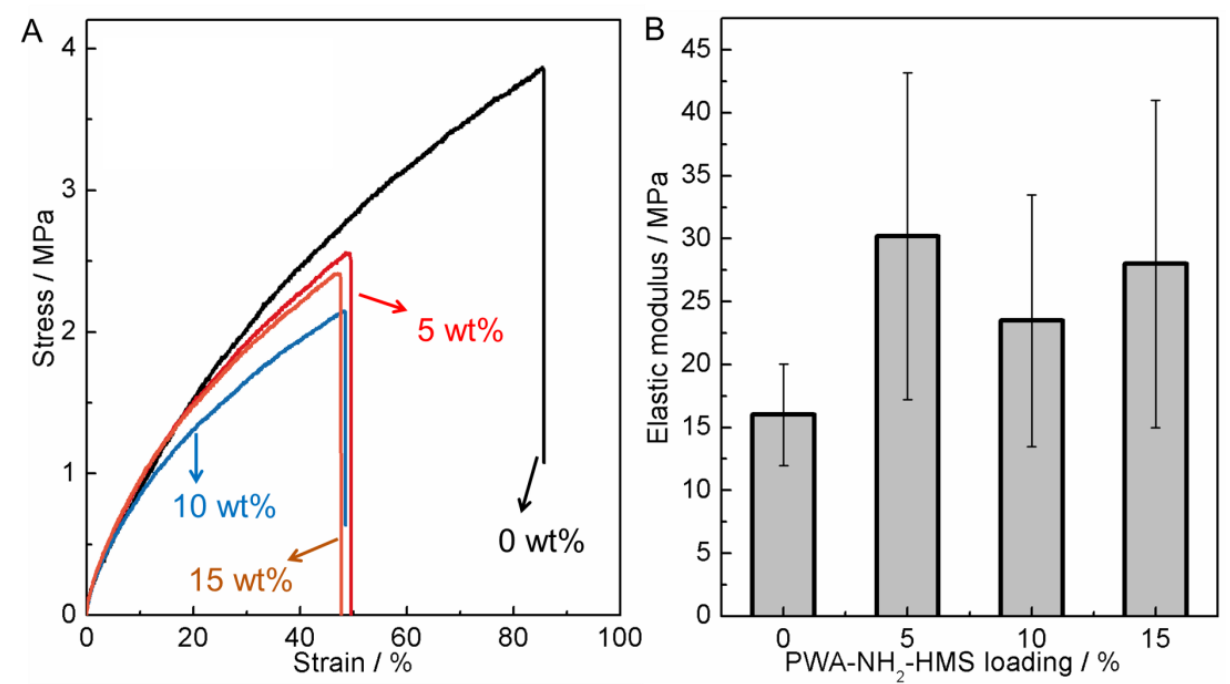

Figure 10. (A) Stress-strain curves and (B) the corresponding elastic modulus for the composite membranes with PWA- $\mathrm{NH}_{2}-\mathrm{HMS}$ loading of $0-15 \mathrm{wt} . \%$ after PA doping. The standard deviations of the elastic modulus are indicated by the error bars. 

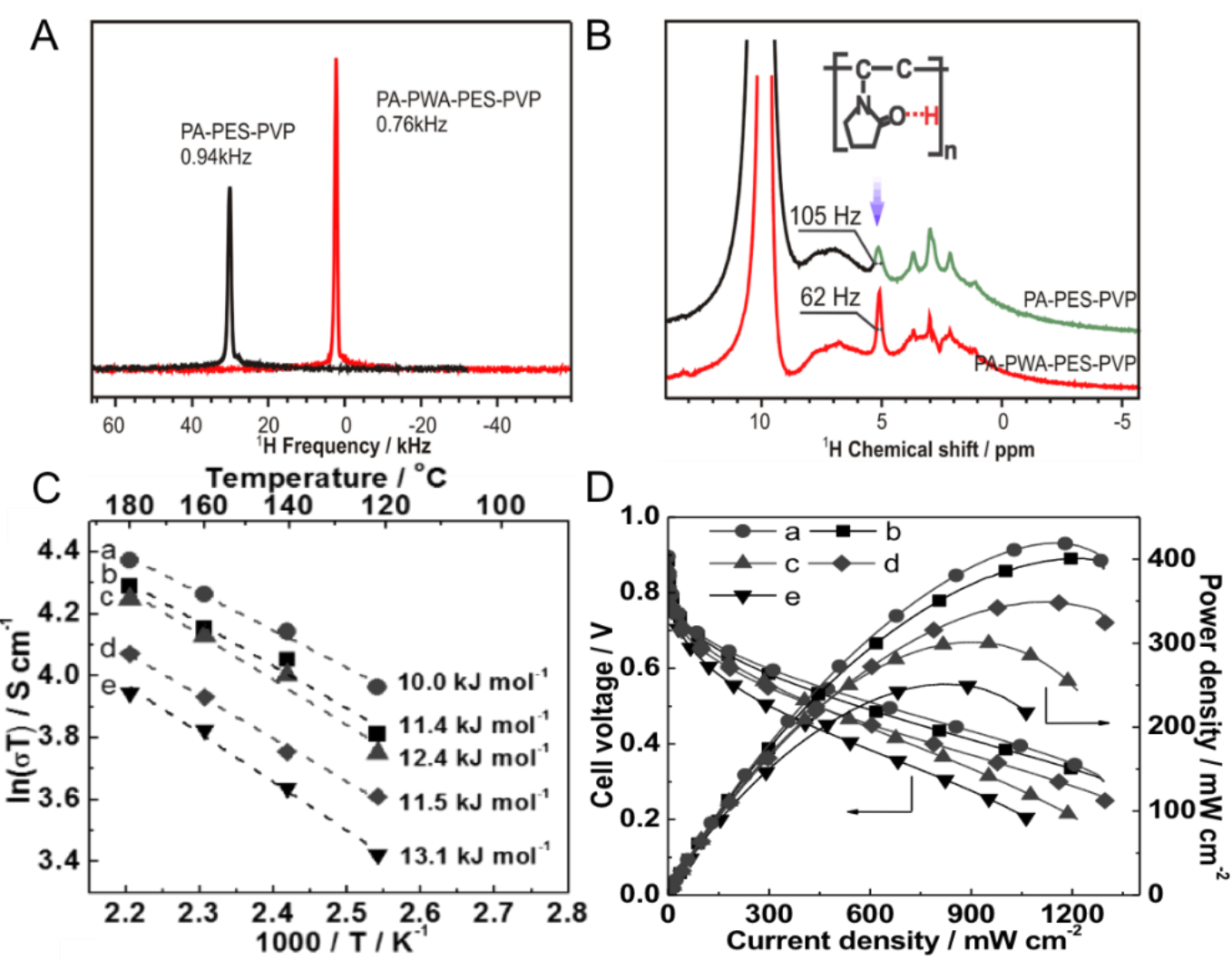

Figure 11. (A) ${ }^{1} \mathrm{H}$ frequency and (B) ${ }^{1} \mathrm{H}$ chemical shift for PES-PVP with PA and PWA as proton conductors; (C) Arrhenius plot of proton conductivity and (D) single cell performance

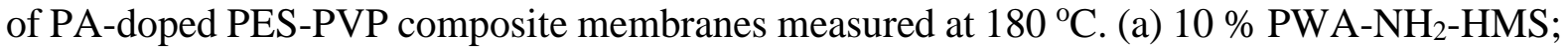
(b) $5 \%$ PWA-NH $-\mathrm{HMS}$; (c) $15 \%$ PWA-NH $\mathrm{NH}_{2}-\mathrm{HMS}$; (d) $10 \% \mathrm{NH}_{2}-\mathrm{HMS}$; (e) pristine PESPPV composite membrane. 


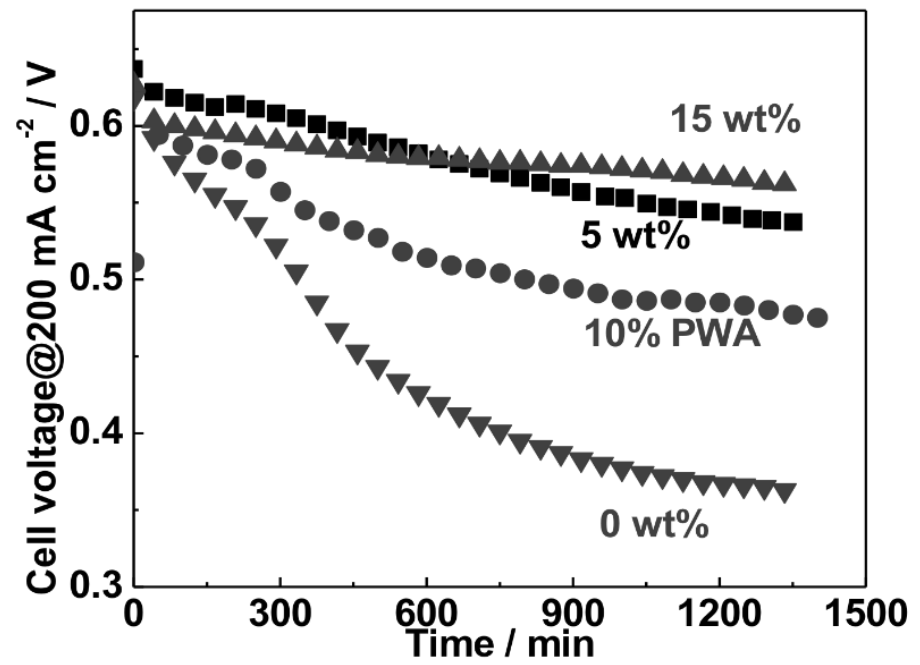

Figure 12. Durability test of PES-PVP based composite membranes with different loading of PWA-NH 2 -HMS at $200{ }^{\circ} \mathrm{C}$ with a current load of $200 \mathrm{~mA} \mathrm{~cm}^{-2}$. 